\title{
Proximal Renal Tubular Acidosis. A Defect in Bicarbonate Reabsorption with Normal Urinary Acidification
}

\author{
J. Rodriguez Soriano, H. Boichis, H. Stark and C. M. Edelmann, Jr. \\ Department of Pediatrics, Albert Einstein College of Medicine, Bronx Municipal Hospital Center, \\ Bronx, N.Y. 10461, USA
}

\section{Extract}

This report concerns two patients with primary renal tubular acidosis (RTA) in whom the abnormality in hydrogen excretion was shown to result from inappropriate urinary loss of bicarbonate due to a low renal bicarbonate threshold. On the basis of the findings, a new definition and reclassification of RTA is proposed.

The clinical course and response to medication is illustrated in figs. 1-4. Repeated measurements of clearances of creatinine, inulin, and PAH gave normal values (table I).

Excretion of aminoacids (table II) was normal in both patients. After water restriction, the urinary osmolality was $990 \mathrm{mOsm} / \mathrm{kg}$ water for K.J. and $1088 \mathrm{mOsm} / \mathrm{kg}$ water for S.G. No reducing substance was found in the urine of K.J.; glucose was present in trace amounts on several occasions in the urine of S.G. Tubular reabsorption of phosphate was always in the normal range, 80 to 90 percent of the filtered amount.

Both children had an adequate response to the oral administration of ammonium chloride, providing no alkali therapy was being administered at the time of the test (table III).

In fig. 5, rates of reabsorption and excretion of bicarbonate, expressed as mmoles/100 $\mathrm{ml}$ glomerular filtrate (GF) are plotted against serum bicarbonate concentration in mmoles/liter. Data from 2 studies are included in the figure. K.J. started to excrete bicarbonate into the urine at a serum bicarbonate level of 18 to $19 \mathrm{mmoles} / \mathrm{liter}$; the Tm of reabsorption was low, being approximately $2.1 \mathrm{mmoles} / 100 \mathrm{ml}$ GF. In S.G., although the threshold was similarly depressed (19 to $20 \mathrm{mmoles} / \mathrm{liter}$ ), the Tm of reabsorption was at the lower limit of the normal range (2.5 to $2.6 \mathrm{mmoles} / 100 \mathrm{ml} \mathrm{GF}$ ).

The ratio of reabsorbed bicarbonate to $\mathrm{Tm}$ has been plotted as a function of the ratio of filtered bicarbonate to $\mathrm{Tm}$ (fig. 6). The data from the studies in K.J. demonstrate a splay very similar to that of normal infants. S.G., however, has a markedly increased splay.

During bicarbonate infusion and when rates of bicarbonate reabsorption were near the Tm, acetazolamide was administered intravenously in a single dose of $100 \mathrm{mg}$. In both children, marked inhibition of bicarbonate reabsorption was demonstrated. At similar rates of filtered bicarbonate, the urinary excretion increased two-to-three-fold with a concomitant decrease in the rate of reabsorption (table V).

Results for glucose reabsorption in K.J. are close to those of normal adults with a threshold of $300 \mathrm{mg} / \mathrm{min} / 1.73 \mathrm{~m}^{2}$ and a Tm of over 400 . In contrast, S.G. had small amounts of glucose in the control urines and the glucose threshold was abnormally low, approximately $100 \mathrm{mg} / \mathrm{min} / 1.73 \mathrm{~m}^{2}$. Although blood glucose was not maintained at high values long enough to be certain that the $\mathrm{Tm}$ had been reached, values as high as $327 \mathrm{mg} / \mathrm{min} / 1.73 \mathrm{~m}^{2}$ were obtained, suggesting that his glucose $\mathrm{Tm}$ was normal. 
After administration of histamine, the acidity of the gastric fluid increased markedly and the values of free acid and total titratable acid compare closely with that of normal children (table VI).

Histologic examination of a percutaneous renal biopsy specimen from K.J. showed minimal hypercellularity of the glomerular stalks. The lumens of the proximal convoluted tubules were frequently open; no significant histologic abnormalities were seen. No glomerular or tubular abnormalities were observed in a biopsy specimen from S.G.

Both patients reported here were able to respond normally during metabolic acidosis with excretion of very acid urine containing adequate amounts of titratable acid and ammonium. However, when alkali was administered and serum bicarbonate levels were brought into the range of normal, the urine, normally neutral or slightly acid at this time, contained inappropriately large amounts of bicarbonate and was consistently alkaline.

During bicarbonate titration, bicarbonate was found in urine only when the threshold was exceeded. Below this level, the urine was normally acid and therefore bicarbonate free. At a plasma bicarbonate concentration above the threshold, an abrupt increase in urine bicarbonate concentration occurred, as in the normal subject. This observation helps to differentiate this type of abnormality from the bicarbonate loss in gradient type RTA, in which a small constant rate of excretion of bicarbonate in urine persists despite lowering of plasma bicarbonate concentration well below threshold values.

A satisfactory classification of RTA must take into account patients with acidification defects as well as those with abnormalities in bicarbonate reabsorption. A distinction should also be made between primary and secondary disease.

RTA is a condition in which there is a defect in renal excretion of hydrogen or reabsorption of bicarbonate, or both, out of proportion to impairment of glomerular filtration. It is suggested that RTA be divided into two forms: 1. a proximal form caused by a defect in bicarbonate reabsorption; and 2. a distal form due to inability to establish an adequate $\mathrm{pH}$ gradient between blood and distal tubular fluid. Although $\mathrm{pH}$ gradients are established throughout the length of the nephron and bicarbonate reabsorption is not confined to the proximal segment, most filtered bicarbonate is reabsorbed in the proximal tubule whereas production of ammonium and titratable acid with low urinary $\mathrm{pH}$ is primarily a distal function. The patients described belong to the first category and as such represent a new form of RTA.

Patients with proximal RTA require inordinately high doses of citrate or bicarbonate to maintain serum bicarbonate levels within the normal range, due to the great loss of bicarbonate in urine. Failure of a patient with RTA to respond to usual doses of bicarbonate may be a clue that the defect is of the proximal type.

\section{Speculation}

The studies presented appear to justify distinguishing between two types of renal tubular acidosis; one resulting from a proximal tubular lesion, the other a distal malfunction. Since the ultimate prognosis seems to vary with the site of the acidification deficit, this distinction has more than academic importance.

\section{Introduction}

The term renal tubular acidosis (RTA) is used to indicate a state of tubular insufficiency with regard to renal excretion of hydrogen ion which is out of proportion to, or occurs in the absence of glomerular insufficiency. Primary $R T A$ refers to an entity in which the abnormality is present as an isolated tubular defect; it is distinguished from secondary $R T A$, which occurs in as- sociation with multiple tubular abnormalities (Fanconi syndrome, oculo-cerebro-renal syndrome of Lowe), inborn metabolic ciefects (galactosemia, fructose intolerance, Wilson's disease, lactose intolerance), hypercalcemia, potassium depletion, certain cases of chronic pyelonephritis, and obstructive uropathy.

Net excretion of hydrogen ion in urine can be expressed by the relationship: $\mathrm{H}^{+}=\mathrm{TA}+\mathrm{NH}_{4}{ }^{+}-\mathrm{HCO}_{3}$ where $\mathrm{H}^{+}$represents rate of urinary excretion of hy- 
drogen ion, TA titratable acid, $\mathrm{NH}_{4}{ }^{+}$ammonium, and $\mathrm{HCO}_{3}$ bicarbonate. Abnormalities underlying deficient excretion of hydrogen ion, therefore, might include: 1. impaired excretion of titratable acid or ammonium or both

2. loss of bicarbonate into the urine due to incomplete reabsorption or

3. a combination of 1 and 2

In patients with RTA the finding of bicarbonate in urine concomitant with reduced concentrations of bicarbonate in blood initially led to the interpretation that the basic abnormality was in the mechanism for bicarbonate reabsorption $[35,73]$. In recent years, however, it has been recognized that the defect resides in the inability to establish a sufficient gradient of $\mathrm{pH}$ between blood and tubular fluid to allow for excretion of adequate quantities of titratable acid and ammonium $[56,77]$. In all patients with primary RTA heretofore studied, bicarbonate reabsorption has been found to be normal $[56,59,64,65,71]$.

We report here two patients with primary RTA in whom the abnormality in hydrogen excretion was shown to be inappropriate urinary loss of bicarbonate, due to a low renal plasma bicarbonate threshold. On the basis of these findings, a new definition and reclassification of RTA is proposed [17].
First patient (figs. 1 and 2). K.J. was born on April 22, 1963, of a 22-year-old Negro female, gravida 2, para 2. Delivery was at term and uncomplicated, although birth weight was only $2.24 \mathrm{~kg}$ and length $48 \mathrm{~cm}$. He did well in the premature nursery and was discharged at two weeks of age, weighing $2.32 \mathrm{~kg}$. A routine urinalysis at one week of age was normal.

At home he did well for a short time, but then began to feed poorly; he refused milk but continued to eat cercal. Following the onset of mild diarrhea without vomiting, he was hospitalized on May 27, 1963, at 25 days of age. He was markedly dehydrated, cachectic and tremulous. Weight was $2.20 \mathrm{~kg}$, temp. $99^{\circ} \mathrm{F}$, heart rate 140 per minute, respiratory rate 30 per minute. Liver was palpated $1.5 \mathrm{~cm}$ below the costal margin. The remainder of the examination was unremarkable. Laboratory data on admission included the following: hematocrit $50 \%$, blood urea $26.8 \mathrm{mmoles} / \mathrm{l}$, Na 159 and $\mathrm{Cl} 138 \mathrm{mEq} / \mathrm{l}$, and total $\mathrm{CO}_{2}\left(\mathrm{tCO}_{2}\right) 14.8 \mathrm{mmoles} / \mathrm{l}$. Urinalysis revealed the following: $\mathrm{pH} 5$, trace of protein and no cells. Blood, stool, and urine cultures were negative.

On admission the diagnosis of sepsis was suspected; penicillin and streptomycin were given for ten days in addition to conventional intravenous fluids. After three

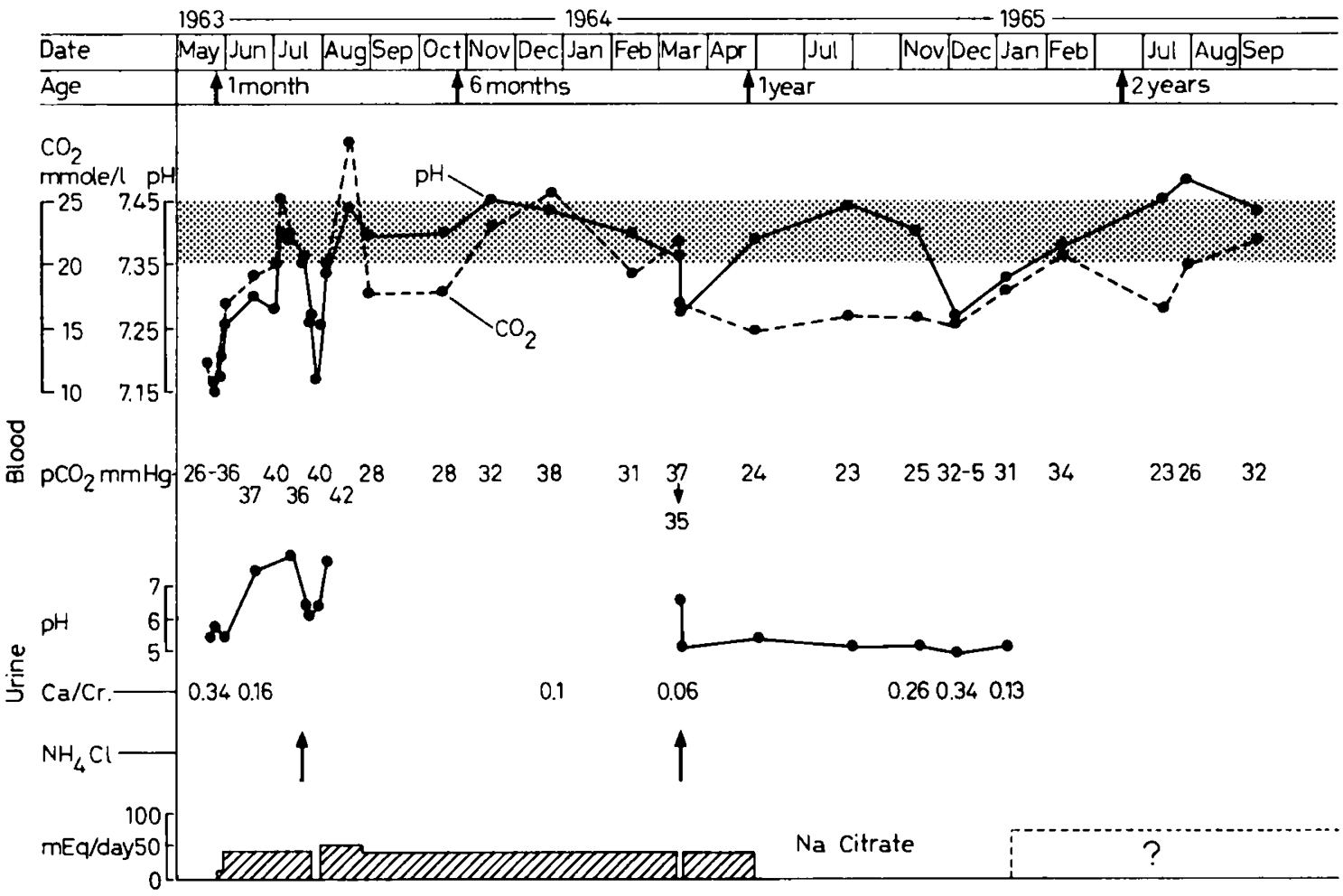

Fig. 1. Clinical course in K.J. Biochemical features, as influenced by citrate therapy. 
days of therapy the infant was markedly improved, having gained 320 grams in weight.

On the sixth hospital day, hyperchloremic acidemia was still present despite complete correction of the dehydration. The laboratory findings were: $\mathrm{pH} 7.17$; $\mathrm{Na} 132 ; \mathrm{Cl} 120 ; \mathrm{K} 5.2 ; \mathrm{tCO}_{2} 10.0 \mathrm{mEq} / \mathrm{l}$; urea 6.8; $\mathrm{Ca} 7.7 \mathrm{mg} / 100 \mathrm{ml}$. The urine $\mathrm{pH}$ was 5.5 and the ratio in urine of calcium to creatinine was $0.34 .^{1}$

The acidosis persisted and he was started on an oral citrate mixture (10 mEq per day) and calcium gluconate. On the tenth hospital day the blood $\mathrm{pH}$ was 7.18 , $\mathrm{tCO}_{2} 12.5 \mathrm{mEq} / \mathrm{l}$ and $\mathrm{Cl} 115 \mathrm{mEq} / \mathrm{l}$. The dose of citrate was increased to $40 \mathrm{mEq} /$ day $(16 \mathrm{mEq} / \mathrm{kg}$ ) with gradual and complete correction of the acidemia. The effect of this therapy was remarkable in that the baby gained $2 \mathrm{~kg}$ in the following two months. While receiving citrate, the urine $\mathrm{pH}$ was consistently above 7 , and the $\mathrm{Ca} / \mathrm{Cr}$ ratio decreased to 0.16 .

At three months of age citrate therapy was stopped. There was immediate reappearance of the hyperchloremic acidosis which disappeared promptly with reinstitution of therapy. The infant was discharged on

1 Data in 46 normal children studied in this laboratory showed mean $\mathrm{Ca} / \mathrm{Cr}$ in 12 hours, overnight urine collections of 0.051 with standard deviation of 0.038 .
August 9, 1963, at three and a half months of age, in good health, weighing $4.96 \mathrm{~kg}$. He received a regular diet plus $40 \mathrm{mEq} /$ day of sodium citrate.

For the subsequent months he did well. Serial determinations of $\mathrm{pH}, \mathrm{tCO}_{2}$, urea and electrolytes in blood were consistently normal and repeated urine cultures were negative. His growth and development during this period were normal.

During the second year of life, therapy was discontinued by the mother. $\mathrm{tCO}_{2}$ in blood again fell below normal limits, although $\mathrm{pH}$ was normal when measured, by virtue of compensatory hypocapnia caused by crying. ${ }^{2}$ The $\mathrm{pH}$ of the urine during this period was consistently acid. Growth slowed markedly until his height and weight were again below the 3 rd percentile for his age.

Therapy was restarted in January 1965 and the child was hospitalized again in February at 22 months of age. Physical examination was unremarkable. Roentgenographic studies showed no evidence of rickets or nephrocalcinosis.

${ }^{2}$ In our experience, $\mathrm{pH}$ of blood in infants and small children frequently is misleading duc to the marked changes in $\mathrm{pCO}_{2}$ that occur with breath holding and crying.

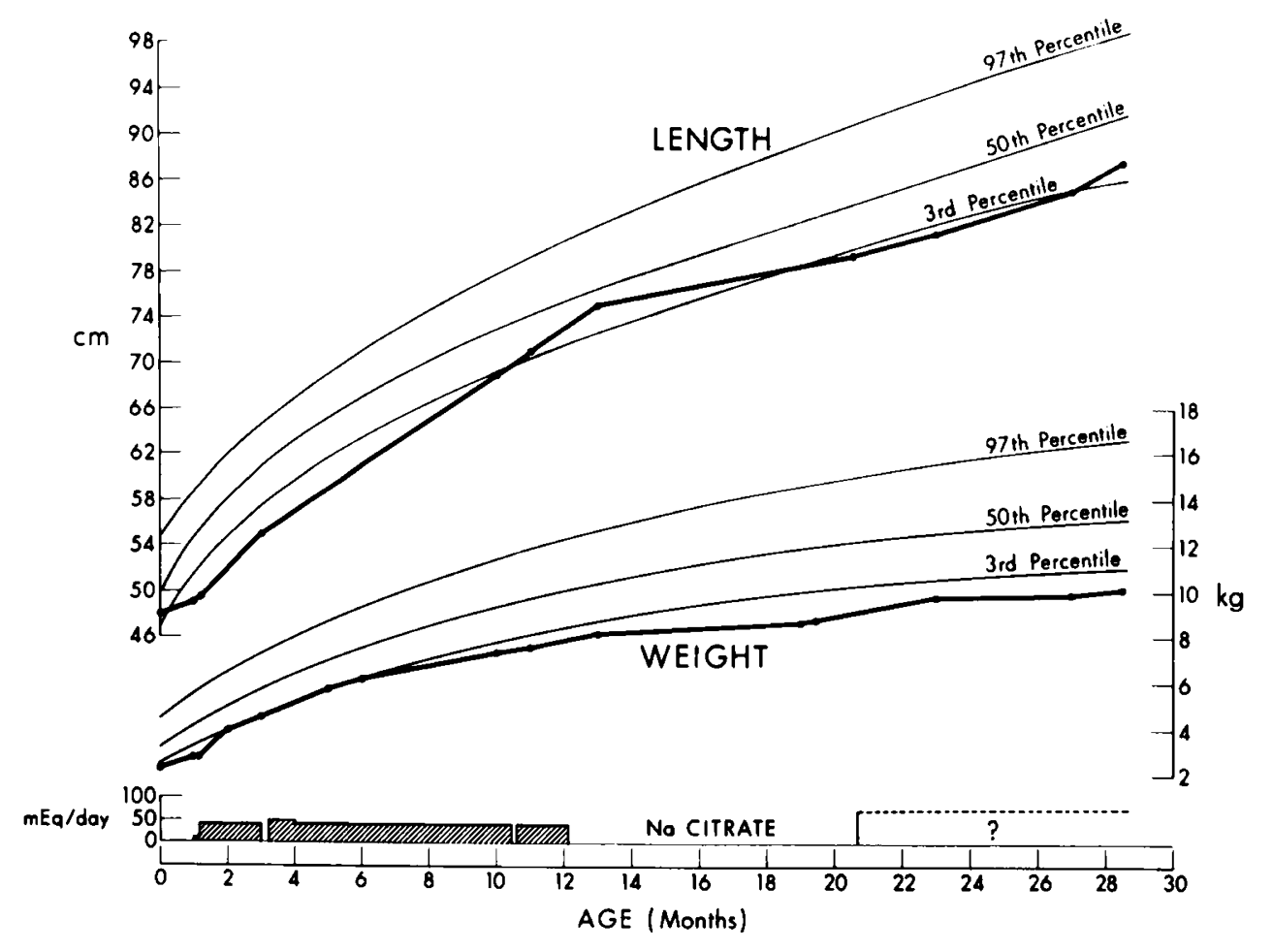


Following this hospitalization attempts were made to continue the dose of citrate at a level of $75 \mathrm{mEq} /$ day; however, it was apparent from studies of blood and urine that administration of the medication was very irregular.

An older sibling - when three years old-was at the 3rd percentile for height and weight. His blood acidbase balance was normal and his response to ammonium chloride administration was adequate.

Second patient (figs. 3 and 4). S. G. was born on February 1,1962 , of a 36-year-old white female, gravida 3 para 3. Delivery was at term and uncomplicated. Birth weight was $3.21 \mathrm{~kg}$. He had no neonatal problems other than frequent vomiting; his weight at one month of age was only $2.95 \mathrm{~kg}$. Vomiting subsided shortly thereafter but he continued to develop poorly, failing to attain the 3rd percentile for length or weight. Psychomotor development also was slow.

He was first seen at the Bronx Municipal Hospital Center at 15 months of age because of failure to grow. Except for his small size, physical examination was negativc. Following demonstration of a moderately severe hyperchloremic acidosis, he was referred to the Pediatric Renal Unit for investigation, and subsequently hospitalized at the age of 18 months. Physical examination on admission was unremarkable; length was $72 \mathrm{~cm}$ and weight $8.8 \mathrm{~kg}$. Laboratory data on blood were as follows: $\mathrm{pH} 7.32, \mathrm{tCO}_{2} 17$ to $20 \mathrm{mmoles} / \mathrm{l}$; $\mathrm{Na} 139$ to $133 ; \mathrm{K} 5.3$ to $5.8 ; \mathrm{Cl} 106$ to $111 \mathrm{mEq} / \mathrm{l}$; Ca $9.7 \mathrm{mg} / 100 \mathrm{ml}$.

Urinalysis and urine cultures were consistently negative. Calcium excretion in the urine over a period of 24 hours was $3.2 \mathrm{mg} / \mathrm{kg}$ with a urinary $\mathrm{Ca} / \mathrm{Cr}$ ratio of 0.31. Urinary concentration following an overnight thirst was $940 \mathrm{mOsm} / \mathrm{kg}$ of water. Intravenous pyelogram was normal and neither rickets nor nephrocalcinosis was evident radiologically. Bone age was retarded; only 8 epiphyses were present in the hemiskeleton.

Following discharge he was started on continuous citrate therapy. With dosage of 50 and then $65 \mathrm{mEq} /$ day $\mathrm{pH}$ of the blood remained in the low normal range. When the dose was increased to $100 \mathrm{mEq} /$ day (11 $\mathrm{mEq} / \mathrm{kg}$ ) full correction of the acidosis resulted and the urinary calcium excretion decreased to $1.1 \mathrm{mg} / \mathrm{kg}$ and the $\mathrm{Ca} / \mathrm{Cr}$ ratio to 0.10 . The effect on growth was remarkable. He grew $9 \mathrm{~cm}$ in 9 months and approached the 3rd percentile for the first time. An effect on psychomotor development also was evident and in a few months he started to walk and talk, catching up with his chronological age.

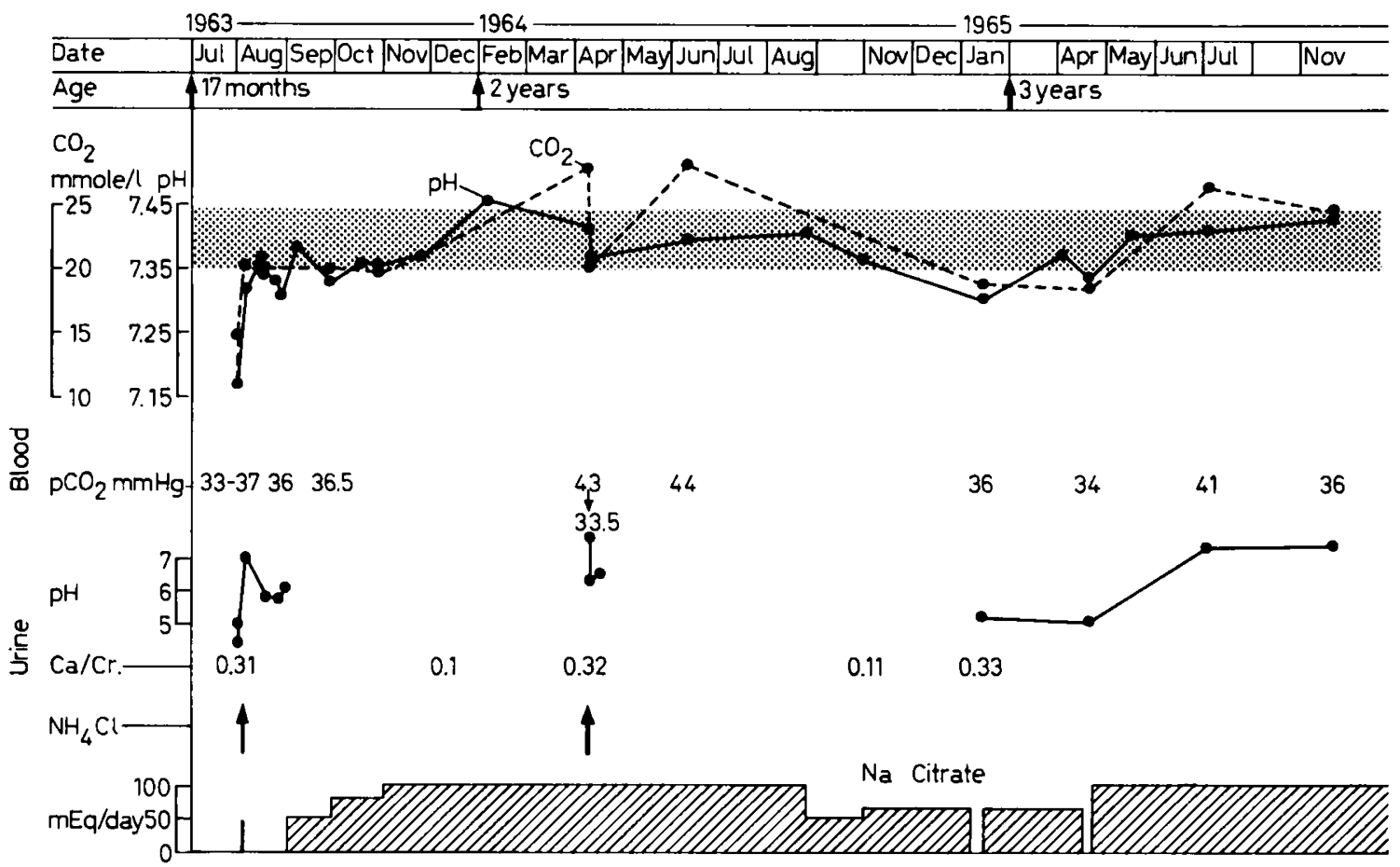

Fig. 2. Effect of citratc therapy on growth of K.J.
Fig. 3. Clinical course in S.G. Biochemical features, as influenced by citrate therapy. 
When citrate therapy subsequently was decreased to a dose of 50 to $65 \mathrm{mEq} /$ day, the blood $\mathrm{pH}$ fell again to the low normal range and the $\mathrm{Ca} / \mathrm{Cr}$ ratio increased to 0.33 . There was no apparent effect on growth, however, with a gain of $5 \mathrm{~cm}$ in 7 months. Cessation of therapy produced a prompt return of the hyperchlorcmic acidosis.

In April 1965, at age $3 \frac{1}{4}$ years, he was rehospitalized for further study. Physical examination was negative. At that time, after several days without therapy, $\mathrm{pH}$ in the blood was $7.33, \mathrm{tCO}_{2}$ was 18.6 , and urine $\mathrm{pH}$ was 5.1 . Following discharge he was again given $100 \mathrm{mEq} /$ day of sodium citrate. On this therapy he has maintained a normal acid-base balance. His growth has been parallel to slightly below the 3rd percentile. Other family members are in good health. Unfortunately, they could not be investigated.

\section{Methods and Procedures}

Quantitative urine collections of short duration were made utilizing an indwelling urethral catheter. Blad-

Fig.4. Effect of citrate therapy on growth of S.G. der emptying was assured by means of air wash-out and application of suprapubic pressure, except as noted. The initial urine obtained during each clearance study was utilized for urinalysis and culture. Bacteriuria was never demonstrated in these urines nor in clean-voided urine specimens collected serially following catheterization. Inulin, PAH, and endogenous creatinine clearances were performed using standard techniques.

Ammonium chloride was administered orally, through a gastric tube, in a single dose of $75 \mathrm{mEq} / \mathrm{m}^{2}$ [16]. Hourly urine collections were obtained 2 hours prior to and 5 hours following the load. Capillary and venous blood samples were obtained prior to and 3 hours after the load.

Investigation of bicarbonate reabsorption was performed by the continuous infusion of a solution containing sodium bicarbonate, inulin and PAH [18]. Bicarbonate, withheld from the initial infusion to permit control collections, was subsequently infused at a rate calculated to produce an increase in serum bicarbonate concentration of $2 \mathrm{mEq} / \mathrm{l} / \mathrm{hr}$. When the bicarbonate threshold was reached, as judged by increase in $\mathrm{pH}$ of the urine to 6.5 to 7.0 , the rate of infusion of bicarbonate was increased by a factor of $11 / 2$ to 2. Urine was collected at one half hour intervals, at

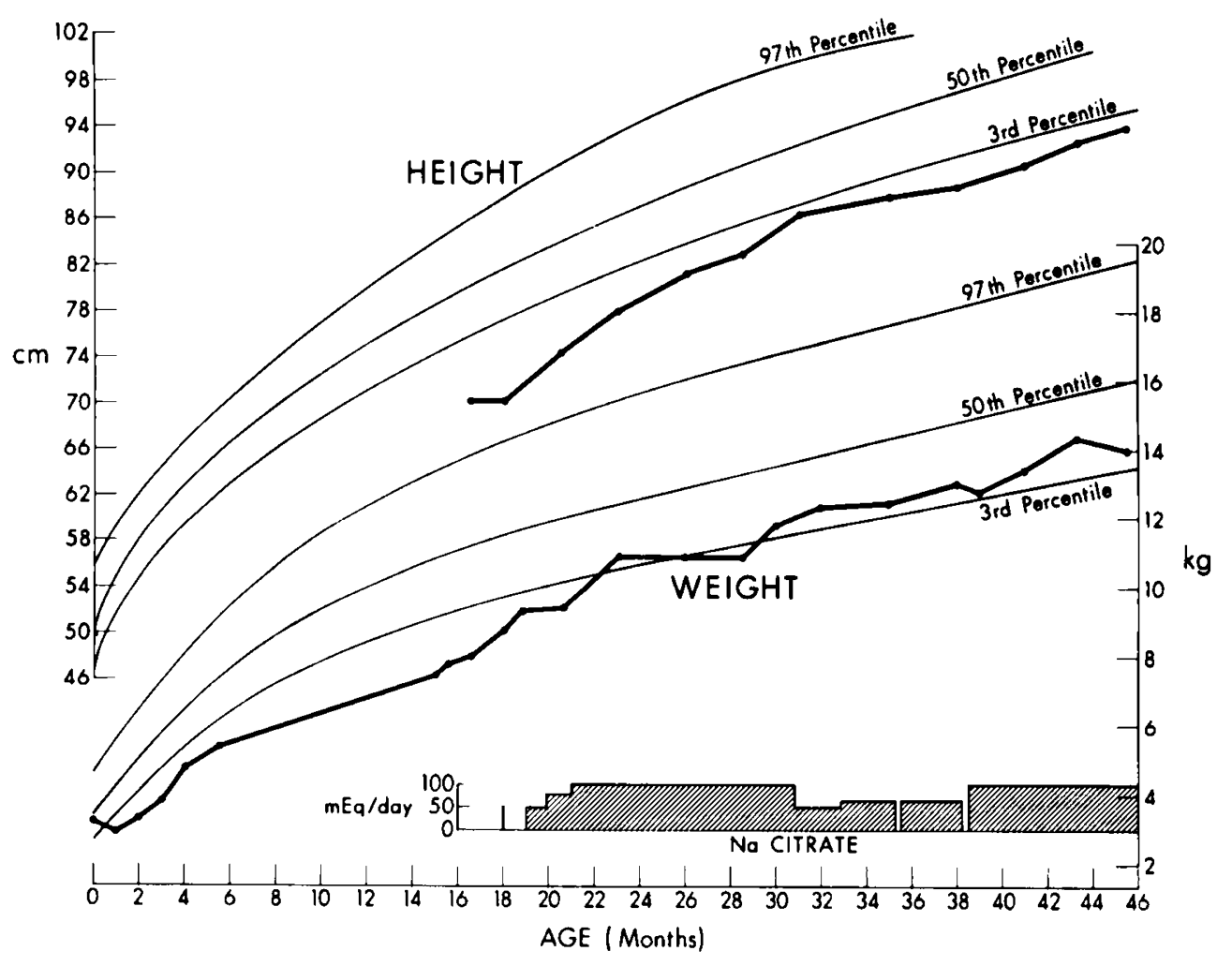


the mid-point of which blood samples were obtained, until serum bicarbonate concentrations exceeded 30 to $32 \mathrm{mmoles} / \mathrm{l}$ for several periods. Acetazolamide was then administered intravenously in a single dose of $100 \mathrm{mg}$ and collections continued for 2 to 4 additional periods. Curves of bicarbonate reabsorption and excretion ${ }^{3}$ were constructed and plotted according to the method of PrTts $e t$ al. [51]. Corrections were not made for cither Donnan equilibria or transit time between glomerulus and urinary bladder. During this test, urine was collected under mineral oil and completeness of collection assured by manual suprapubic pressure. Freely flowing venous blood was obtained from an indwelling needle placed in a superficial vein of the arm or hand.

Investigation of glucose reabsorption was performed utilizing a similar technique. A solution containing inulin was administered at a constant rate throughout the study. Glucose $(30 \%)$ was infused at progressively higher rates from a separate flask. $\Lambda 20$-minute equilibration period followed each successive increment in glucose infusion rate in order to allow blood concentration to stabilize. Curves of glucose reabsorption were calculated according to the method of SMiтH et al. [70].

The $\mathrm{pH}$ of blood and urinc were measured at $38^{\circ} \mathrm{C}$ with a Radiometer $\mathrm{pH}$ meter and micro-electrode chain. Carbon dioxide content was determined by the method of VAN SLYKE and Neill [76], using a Natelson microgasometer. The carbon dioxide tension $\left(\mathrm{pCO}_{2}\right)$ and bicarbonate concentration were calculated from the Henderson-Hasselbach equation. $\mathrm{A} \mathrm{pK}^{1}$ value of 6.10 and a value for $\alpha$ of 0.0301 were employed for serum. The values for $\mathrm{pK}^{1}$ were calculated for each urine sample according to the formula $6.33-0.5 \mathrm{~V} / \mathrm{B}(29)$, where $B$ represents the total cation concentration estimated as the sum of $\mathrm{Na}+\mathrm{K}$, expressed as $\mathrm{Eq} / \mathrm{l}$.

Titratable acid in urine was measured by immediate titration at $25^{\circ} \mathrm{C}$ to $\mathrm{pH} \mathrm{7.7,} \mathrm{using} \mathrm{a} \mathrm{Coleman}$ Metrion II pH meter. An end point of 7.7 instead of 7.4 was chosen to correct for temperature.

Titratable acid in gastric fluid was measured by titration to $\mathrm{pH} 3.0$ (free acid) and 7.7 (total acid).

The tubular reabsorption of phosphate (TRP) was calculated by the formula TRP $=100 \times\left[1-\frac{U \mathrm{p} \times \mathrm{Scr}}{\mathrm{Ucr} \times \mathrm{Sp}}\right]$

3 The terms bicarbonate titration and glucose titration are used commonly in reports of physiological studies. The term titration has a specific chemical meaning, however, and should not be used to describe changes in renal reabsorption of a substance in response to progressively increasing concentrations of the substance in blood. where Up, Ucr, Sp, and Scr represent the concentrations of phosphate and creatinine in urine and serum respectively.

Ammonium was measured by the micro-diffusion method of Conway [10]. Sodium and potassium were measured utilizing a Perkin Elmer Flame Photometer, model 146. Chloride was determined coulorimetrically using the method and instrument of Cotrove [11]. Inulin was determined by a modification of the method of Schreiner [61]. During the glucose titration, urinary inulin was measured after incubation of the diluted specimen with glucose oxidase. Para-aminohippurate was measured by a modification of the method of Sмiтн et al. [69]. Glucose was determined by the method of Nelson-Somogri $[49,72]$. Calcium, phosphorus, urea and creatinine were measured on the Technicon Auto-Analyzer, using modifications of the methods of KessLer and Wolfman [33] for calcium, Fiske and Subbarow [22] for phosphorus, Marsh, Fingerhut and Kirsch for urea [43], and Chasson. Grady and STANLEY for creatinine [9]. Aminoacids were determined by column chromatography using the Technicon Automatic Aminoacid Analyzer. Osmolality was measured cryoscopically, using either the Fiske or the Advanced Instruments osmometer.

\section{Results}

\section{Glomerular Filtration Rate and Renal Plasma Flow}

Repeated measurements of clearances of creatinine, inulin, and $\mathrm{PAH}$ revealed normal values (table I).

\section{Tubular Functions}

Excretion of aminoacids (table II) were normal in both patients. After water restriction, the urinary osmolality was $990 \mathrm{mOsm} / \mathrm{kg}$ water in K.J. and $1088 \mathrm{mOsm} / \mathrm{kg}$ water in S.G. Normal values in this laboratory for children aged 2 to 16 months average $1089 \mathrm{mOsm} / \mathrm{kg}$,

Table I. Renal clearances

\begin{tabular}{|c|c|c|c|c|c|c|}
\hline & Date & $\begin{array}{l}\text { Age } \\
\text { mos. }\end{array}$ & $\begin{array}{l}\text { Surface } \\
\text { area } \\
\mathrm{m}^{2}\end{array}$ & $\begin{array}{l}\text { Creat } \\
\text { nine } \\
\mathrm{ml}\end{array}$ & $\begin{array}{l}\text { Inulin } \\
\min / 1.7\end{array}$ & $\begin{array}{l}\mathrm{PAH} \\
3 \mathrm{~m}^{2}\end{array}$ \\
\hline \multirow[t]{4}{*}{ K.J. } & $7 / 18 / 63$ & 3 & 0.25 & - & 86 & - \\
\hline & $3 / 12 / 64$ & 11 & 0.37 & 120 & 95 & 404 \\
\hline & $12 / 3 / 64$ & 20 & 0.44 & 116 & 103 & 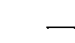 \\
\hline & $1 / 6 / 65$ & 21 & 0.44 & - & 97 & 463 \\
\hline \multirow[t]{4}{*}{ S.G. } & $7 / 29 / 63$ & 18 & 0.40 & 89 & - & - \\
\hline & $4 / 9 / 64$ & 26 & 0.49 & 82 & - & $\ldots$ \\
\hline & $1 / 14 / 65$ & 35 & 0.54 & 96 & 106 & 396 \\
\hline & $4 / 21 / 65$ & 39 & 0.56 & 103 & 94 & - \\
\hline
\end{tabular}


Table II. Excretion of aminoacids in urine

\begin{tabular}{|c|c|c|c|c|c|c|c|}
\hline Date & & & & & & $\begin{array}{l}\mathrm{K} . \mathrm{J} . \\
2 / 12 / 65 \\
\mu \text { moles } / \mathrm{kg}\end{array}$ & $\begin{array}{c}\text { S.G. } \\
\text { 12/4/63 } \\
\text { /24 hours }\end{array}$ \\
\hline Cysteic acid. & . & 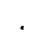 & . & . & . & 0.7 & 0.7 \\
\hline Aspartic acid & . & . & . & . & . & 2.3 & 1.1 \\
\hline Threonine & . . & . & 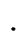 & . & . & 5.4 & 2.4 \\
\hline Serine . . & . . & . & . & . & . & 2.5 & 4.0 \\
\hline Glycine . . & . . & . & . & . & . & 8.1 & 16.0 \\
\hline Alanine . & . . & . & . & . & . & 7.9 & 6.4 \\
\hline Valine . . & . . & . & . & . & . & 2.1 & 1.4 \\
\hline Cystine. . & . . & . & $\cdot$ & . & . & 1.2 & 1.3 \\
\hline Isoleucine . & . . & . & . & . & . & 0.2 & trace \\
\hline Leucine . . & . . & . & $\cdot$ & . & . & 4.3 & 2.0 \\
\hline Tyrosine . & . . & . & r & . & & 1.2 & 1.4 \\
\hline Phenylalanin & ne. & . & & . & . & 3.5 & 0.8 \\
\hline Ornithine & . . & . & 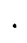 & ${ }^{\circ}$ & - & 0.5 & 1.1 \\
\hline Lysine . . . & . . & . & ${ }^{\circ}$ & 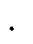 & • & 0.8 & 2.6 \\
\hline Histidine . & . . & . & . & . & $\cdot$ & 10.0 & 5.1 \\
\hline Arginine . & . . & . & ${ }^{\circ}$ & . & . & 0.2 & 0.5 \\
\hline
\end{tabular}

Fig.5. Bicarbonate reabsorption and excretion in K.J. and S.G., compared with that of normal infants. with a normal range of 869 to 1310 (mean \pm 2 S.D.) [15]. Examination for reducing substances in the urine was consistently negative in K.J. In S.G. glucose was present in trace amounts on several occasions. Tubular reabsorption of phosphate (TRP) estimated repeatedly in both patients was always in the normal range of 80 to 90 percent of the filtered load.

Ammonium chloride load (table III). Both children had an adequate response to the oral administration of ammonium chloride, providing no alkali therapy was being administered at the time of the test. In both subjects, $\mathrm{pH}$ in the urine and hydrogen ion excretion in the form of titratable acid and ammonium were comparable to those of controls of similar age [16].

Bicarbonate reabsorption. A test of bicarbonate reabsorption was performed to determine the plasma threshold of excretion and maximal rate of reabsorption (Tm).

In fig. 5 rates of reabsorption and excretion of bicarbonate, expressed as mmoles/100 $\mathrm{ml}$ glomerular filtrate (GF) are plotted against serum bicarbonate concentration in mmoles/l. The diagonal line in the figure represents the rate of filtration of bicarbonate in

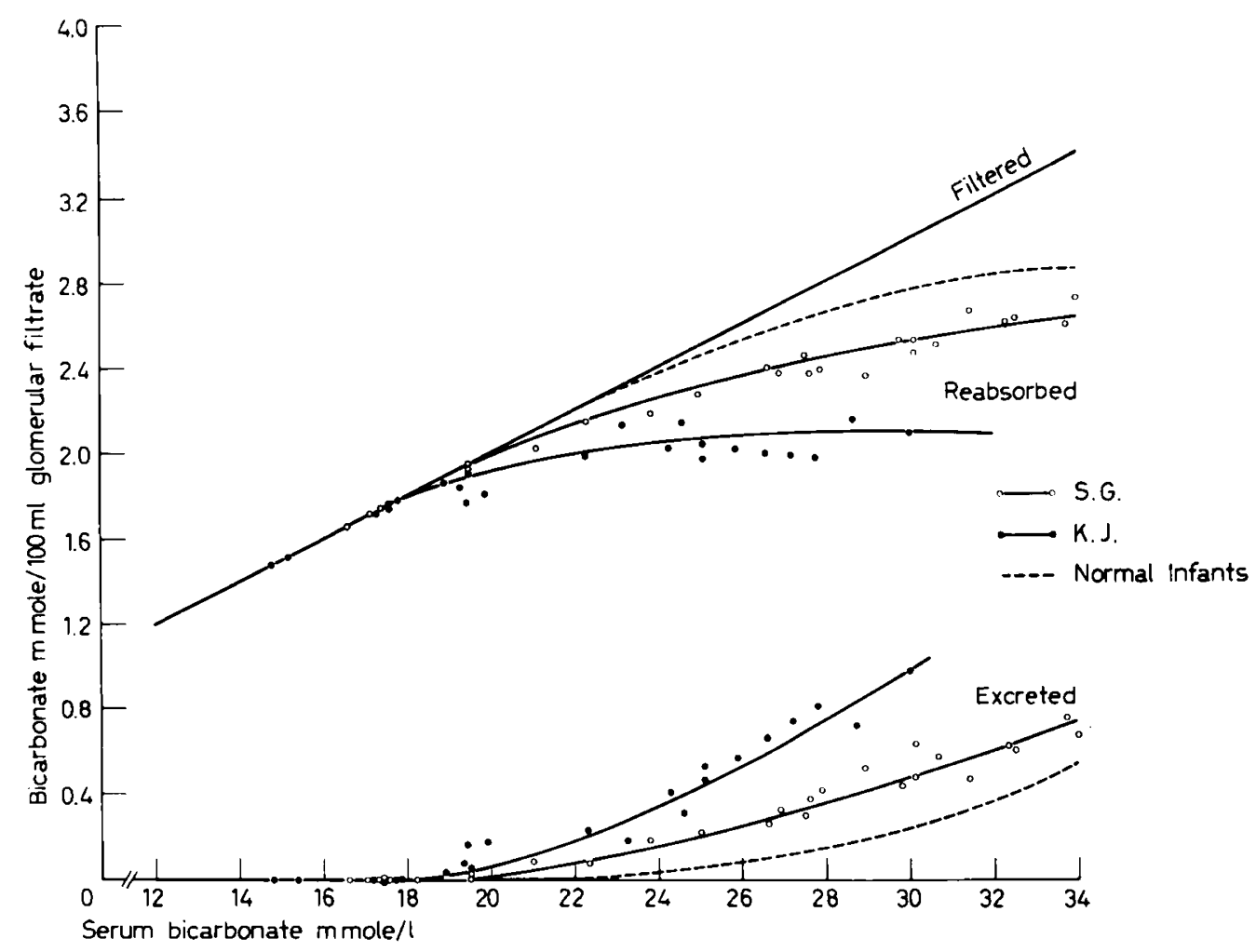


Proximal renal tubular acidosis. A defect in bicarbonate reabsorption with normal urinary .. 89

mmoles/100 $\mathrm{ml} \mathrm{GF}$. As shown in the figure, urinary excretion of bicarbonate remained essentially zero in normal infants [18] until serum concentrations reached $22 \mathrm{mmoles} / \mathrm{l}$, a threshold lower than that found by Pirrs et al. [51] in 3 normal adults, 26 to $28 \mathrm{mmoles} / \mathrm{l}$. The maximum rate of tubular reabsorption in infants, however, is identical to that of adults $[16,51], 2.6$ to $2.9 \mathrm{mmoles} / 100 \mathrm{ml} \mathrm{GF}$.

Bicarbonate reabsorption was studied twice in each patient. Data from both studies are included in the figurc. K.J.started to excrete bicarbonate into the urine at bicarbonate levels in serum of 18 to $19 \mathrm{mmoles} / 1$; the $\mathrm{Tm}$ of reabsorption was low, being approximately $2.1 \mathrm{mmoles} / 100 \mathrm{ml} \mathrm{GF}$. In S.G., although the threshold was similarly depressed (19 to $20 \mathrm{mmoles} / \mathrm{l}$ ), the Tm of reabsorption was at the lower limit of the normal range ( 2.5 to $2.6 \mathrm{mmoles} / 100 \mathrm{ml} \mathrm{GF}$ ).

Since the bicarbonate threshold can vary with the circumstances under which it is determined, particularly with regard to $\mathrm{pCO}_{2}$ of blood, rate of bicarbonate infusion, degree of extracellular volume expansion, rate of urine flow, and electrolyte status of the blood, all tests were performed under identical conditions, utilizing rates of fluid and bicarbonate administration standardized according to weight. The $\mathrm{pCO}_{2}$, potas- sium and chloride concentration in serum before and during the bicarbonate infusion, were comparable in both patients and controls as shown in table IV.

In fig. 6 , the ratio of reabsorbed bicarbonate to $\mathrm{Tm}$ is plotted as a function of the ratio of filtered bicarbonate to Tm. If all nephrons functioned identically and filtered bicarbonate were totally reabsorbed until the Tm was reached, data in normal subjects would fall along the theoretical curve. That this is not the case, is shown by the data of normal infants studied in this laboratory [18]. This deviation from the theoretical line, termed 'splay' is similar to that found by recalculation of data from PrTts [51]. The data from the studies in K.J. demonstrate a splay very similar to that of normal infants. S.G., however, has a markedly increased splay.

Response to acetazolamide. During bicarbonate infusion and when rates of bicarbonate reabsorption were near the $\mathrm{Tm}$, acetazolamide was administered intravenously in a single dose of $100 \mathrm{mg}$. In both children, marked inhibition of bicarbonate reabsorption was demonstrated. At similar rates of filtered bicarbonate the urinary excretion increased two-to-three-fold with a concomitant decrease in the rate of reabsorption

Table III. Ammonium chloride loading

\begin{tabular}{|c|c|c|c|c|c|c|}
\hline Date & $\begin{array}{c}\text { Blood } \\
\mathrm{pH}\end{array}$ & $\mathrm{tCO}_{2}$ & $\mathrm{pCO}_{2}$ & $\begin{array}{l}\text { Urine } \\
\mathrm{pH}\end{array}$ & $\begin{array}{l}\text { Titratable } \\
\text { acid }\end{array}$ & $\mathrm{NH}_{4}+$ \\
\hline & & mmoles/l & $\mathrm{mm} \mathrm{Hg}$ & & \multicolumn{2}{|c|}{$\mu \mathrm{Eq} / \min / 1.73 \mathrm{~m}^{2}$} \\
\hline K.J. $3 / 12 / 64$. & 7.28 & 17.3 & 35 & 5.0 & 52 & 56 \\
\hline S.G. $7 / 29 / 63$. . . . . . & 7.17 & 15.4 & 40 & 4.65 & 75 & 79 \\
\hline Normal (16) (1-16 mønths) & . - & $<18.0$ & - & $\begin{array}{l}4.83^{1} \\
\left(4.5^{-5.05)}\right.\end{array}$ & $\begin{array}{l}62^{2} \\
(43-111)\end{array}$ & $\begin{array}{l}48^{2} \\
(42-99)\end{array}$ \\
\hline
\end{tabular}

1 Mean and range.

2 Mean $\pm 2 \mathrm{SD}$.

Table $I V$. Blood values during bicarbonate infusion

\begin{tabular}{|c|c|c|c|c|c|c|c|c|c|}
\hline \multirow[b]{2}{*}{ Patients } & \multicolumn{3}{|c|}{$\mathrm{pCO}_{2} \mathrm{~mm} \mathrm{Hg}$} & \multicolumn{3}{|c|}{$\mathrm{K} \mathrm{mEq} / \mathrm{L}$} & \multicolumn{3}{|c|}{$\mathrm{Cl} \mathrm{mEq} / \mathrm{L}$} \\
\hline & Control & $\begin{array}{l}\text { At } \\
\text { threshold }\end{array}$ & At Tm & Control & $\begin{array}{l}\text { At } \\
\text { threshold }\end{array}$ & At Tm & Control & $\begin{array}{l}\text { At } \\
\text { threshold }\end{array}$ & At Tm \\
\hline K.J. mean & 33 & 36 & 40 & 4.3 & 4.0 & 3.8 & 103 & 93.5 & 89 \\
\hline S.G. mean & 39 & 35 & 43 & 4.6 & 3.9 & 3.15 & 104 & 103.5 & 93.5 \\
\hline \multicolumn{10}{|l|}{$\begin{array}{l}\text { Normal } \\
\quad \text { infants [18] }\end{array}$} \\
\hline $\begin{array}{l}\text { mean } \\
\text { (range) }\end{array}$ & $\begin{array}{l}35 \\
(29-42)\end{array}$ & $\begin{array}{l}35 \\
(29-40)\end{array}$ & $\begin{array}{l}41 \\
(35-51)\end{array}$ & $\begin{array}{l}4.7 \\
(4.0-5.3)\end{array}$ & $\begin{array}{l}4.2 \\
(3.6-5.2)\end{array}$ & $\begin{array}{l}3.7 \\
(2.9-4.05)\end{array}$ & $\begin{array}{l}103 \\
(103-106)\end{array}$ & $\begin{array}{l}99 \\
(97-101)\end{array}$ & $\begin{array}{l}94 \\
(90-100)\end{array}$ \\
\hline
\end{tabular}




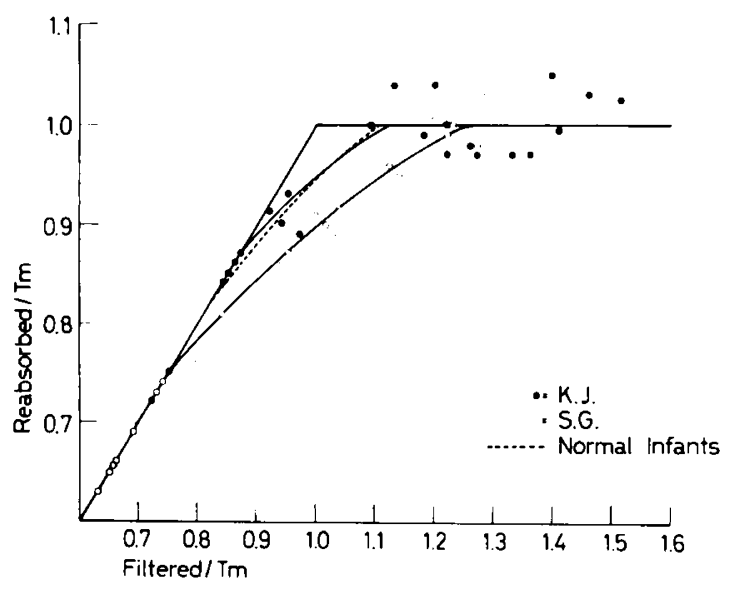

Fig. 6. Splay of bicarbonate reabsorption curves in K.J. and S.G., compared with that of normal infants.

(table V). This response is comparable to that observed in normal infants [75].

Glucose reabsorption. In adults, glucose is absent from the urine until the rate of filtration of glucose exceeds $300 \mathrm{mg} / \mathrm{min} / 1.73 \mathrm{~m}^{2}$. TmG in adult men is 364 $( \pm 89.5)$ and in adult women $303( \pm 55) \mathrm{mg} / \mathrm{min}[68]$.

Table $V$. Effect of acetazolamide on bicarbonate reabsorption

\begin{tabular}{ll}
\hline Time $^{1}$ (min.) & $\mathrm{HCO}_{3}$ mmoles $/ 100 \mathrm{ml} \mathrm{GF}$ \\
& Filtered Excreted Re-
\end{tabular}

absorbed

\section{K.J.}

$\mathrm{NaH} \mathrm{CO}-0.48$ mmoles $/ \mathrm{min}$.

$\begin{array}{llll}440-471 & 2.87 & 0.53 & 2.34 \\ 471-502 & 3.0 & 0.88 & 2.12 \\ 509-\text { Acetazolamide } & & & \\ \quad 100 \mathrm{mg} & & & \\ 502-529 & 3.14 & 1.85 & 1.29 \\ 529-551 & 2.99 & 1.46 & 1.53 \\ 551-571 & 2.85 & 1.18 & 1.67 \\ 571-591 & 2.70 & 1.31 & 1.39\end{array}$

S.G.

$\mathrm{NaH} \mathrm{CO}-0.58$ mmoles/min.

\begin{tabular}{llll}
$424-447$ & 3.23 & 0.62 & 2.61 \\
$447-469$ & 3.40 & 0.67 & 2.73 \\
$472-$ Acctazolamide & & & \\
$\quad 100 \mathrm{mg}$ & & & \\
$469-490$ & 3.52 & 1.24 & 2.28 \\
$490-512$ & 3.36 & 1.62 & 1.74 \\
\hline
\end{tabular}

1 Bicarbonate and acetazolamide are given by intravenous infusion.
Comparable data in children of different ages are not available, but results in K.J. are close to those of normal adults with a threshold of $300 \mathrm{mg} / \mathrm{min} / 1.73 \mathrm{~m}^{2}$ and a $\mathrm{Tm}$ of over 400 . In contrast, S.G. had small amounts of glucose in the control urines and the glucose threshold was abnormally low, approximately $100 \mathrm{mg} / \mathrm{min} /$ $1.73 \mathrm{~m}^{2}$.

Although blood glucose was not maintained at high values long enough to be certain that the $\mathrm{Tm}$ had been reached, values as high as $327 \mathrm{mg} / \mathrm{min} / 1.73 \mathrm{~m}^{2}$ were obtained, suggesting that his glucose $\mathrm{Tm}$ was normal.

Gastric acidity (table VI). After administration of histamine the acidity of the gastric fluid increased markedly and the values found for free acid and total titratable acid are comparable to those found in normal children [12].

A percutaneous renal biopsy was performed on patient K.J. on 2/15/65. Histologic examination showed minimal hypercellularity of the glomerular stalks. The significance of this slight glomerulitis is not known. The lumina of the proximal convoluted tubules were frequently open; no histologic abnormalities were seen.

A percutaneous renal biopsy was also performed on patient S.G. on $4 / 26 / 65$. No glomerular or tubular abnormalities were observed.

Table VI. Gastric fluid acidity

\begin{tabular}{llll}
\hline Time (min.) & $\mathrm{pH}$ & $\begin{array}{l}\text { Free } \\
\text { acidity }\end{array}$ & $\begin{array}{l}\text { Total } \\
\text { acidity } \\
\end{array}$ \\
& $\mu \mathrm{Eq} / \mathrm{ml}$ & $\mu \mathrm{Eq} / \mathrm{ml}$ \\
\hline
\end{tabular}

K.J.

$\begin{array}{llll}\text { fasting } & 5.4 & - & 6.2\end{array}$

histamine phosphate-

$0.1 \mathrm{mg} / \mathrm{kg}^{\mathrm{1}}$

$\begin{array}{llll}0-10 & 3.7 & - & 14.4 \\ 10-30 & 1.9 & 44.7 & 67.5\end{array}$

S.G.

$\begin{array}{llll}\text { fasting } & 2.5 & 13.4 & 37.1\end{array}$

histamine phosphate-

$0.1 \mathrm{mg} / \mathrm{kg}$

$\begin{array}{llll}0-10 & 2.7 & 22.5 & 42.4 \\ 10-20 & 2.0 & 54.8 & 69.3 \\ 20-30 & 1.4 & 59.0 & 85.0\end{array}$

Normal ${ }^{2}$

1-4 years mean $\quad 51.2 \quad 65.1$

(range)

(15-95) (26-106)

${ }^{1}$ Histamine was administered by subcutaneous injection.

2 Data from Cutrer [12]. Maximum values after histamine administration. 


\section{Discussion}

\section{Bicarbonate Reabsorption in Primary RTA}

The diagnosis of renal tubular acidosis is often suggested by the discovery in a patient of hyperchloremic acidosis associated with failure to thrive or stunted growth. The observations reported here are unique, however, in that they represent the first documentation of primary RTA caused by a 'bicarbonate leak' [17].

Classical primary RTA. The patient with the classical form of primary RTA is unable to establish an adequate $\mathrm{pH}$ gradient between blood and urine despite low levels of bicarbonate in plasma; in the presence of severe systemic acidosis he excretes urine with inappropriatcly high $\mathrm{pH}[19,21,56,59,60,62,64,65,71,77]$. The exact nature of the defect in acidification of urine is unknown. Normal carbonic anhydrase activity has been demonstrated in renal tissue [60, 78], although there is enough red blood cell carbonic anhydrase in biopsy tissue to make uncertain the interpretion of these studics. The defect in urinary acidification does not appcar to lie in rate of secretion of hydrogen ions into the tubular lumen, since a marked increase is noted in excretion of titratable acid following infusion of phosphate which increases availability of buffer [56, $71,77]$. The limitation in cstablishing a normal gradient of hydrogen ion between tubular lumen and cell may reside in an inability of the tubule to secrete hydrogen ion against a large gradient, or, more likely, in an increased rate of passive diffusion of hydrogen ion from the lumen back into the cell [65].

Although the absolute rate of ammonium excretion in these patients is low, excretion is adequate when related to the simultaneous $\mathrm{pH}$ of the urine $[21,56,77]$. Excretion of titratable acid is reduced due to incomplete saturation of available urinary buffer.

As a further conscquence of the clevated urinary $\mathrm{pH}$, bicarbonate may be lost into the urine $[56,59,60,62$, $71,77]$. That this bicarbonate leak is not primary, however, has been demonstrated by bicarbonate titrations. The rate of excretion of bicarbonate in urine remains at a constant low level over a wide range of concentration of bicarbonate in plasma, until a normal bicarbonate threshold is reached [59, 64, 65]. At this point the usual, abrupt increase in urine bicarbonate concentration is noted. This result indicates that incomplete reabsorption of filtered bicarbonate at low plasma levels was not due to a defect in the bicarbonate reabsorption mechanism per se but rather to a limitation in the capacity to lower the $\mathrm{pH}$ of tubular fluid. During water diuresis, rate of excretion of bicarbonate is directly proportional to rate of urine flow, indicating again that the factor controlling the amount of bicarbonate reabsorbed is the $\mathrm{pH}$ of tubular fluid and not a limited capacity for reabsorption $[64,65]$. Patients with classical RTA who can acidify their urine to a $\mathrm{pH}$ of 6.2 or below do not, in fact, lose bicarbonate in the urine when they are acidotic. Finally, values for bicarbonate $\mathrm{Tm}$ in patients with classical primary RTA have been shown repeatedly to be within or above the normal range $[56,59,64,65,71]$.

LATNER and BURNARD [35] attempted by means of phosphate infusions in six infants to define the tubular abnormality in RTA. They interpreted their data as demonstrating a defect in reabsorption of bicarbonate in the proximal tubule. Definitive studies were not done, however, and it is realized now that the basic defect in classical RTA is in urinary acidification. The report of LATNER and BURNARD, therefore, although inconclusive, may represent the first demonstration of defective bicarbonate reabsorption as a cause of RTA.

Present patients. Both patients reported here were able to respond norm.dly during metabolic acidosis with excretion of very acid urinc containing adequate amounts of titratable acid and ammonium. However, when alkali was administered and serum bicarbonate levels were brought into the range of normal, the urine, normally neutral or slightly acid at this time, contained inappropriately large amounts of bicarbonate and was consistently alkaline.

Furthermore inappropriate bicarbonate loss was demonstrated during bicarbonate infusion. During the study, bicarbonate was found in urine only when the threshold was exceeded. Below this level, the urine was normally acid and therefore bicarbonate free. At a plasma bicarbonate concentration above the threshold, an abrupt increase in urine bicarbonate concentration occurred, as in the normal subject. This observation helps to differentiate this type of abnormality from the bicarbonate loss in gradient type RTA, in which a small constant rate of excretion of bicarbonate in urine persists despite lowering of plasma bicarbonate concentration to levels well below threshold.

In normal subjects the serum concentration of bicarbonate is maintained at a value slightly below the renal threshold: 28 to $26 \mathrm{mmoles} / 1$ in adults [51], 22 in infants [16]. Under these circumstances virtually all filtered bicarbonate is reabsorbed. If, owing to the acute ingestion or infusion of bicarbonate, serum bicarbonate concentration exceeds the renal threshold, bicarbonate reabsorption is incomplete; urinary excretion of non-reabsorbed bicarbonate then gradually lowers the concentration of bicarbonate in serum and interstitial fluid to a level below the threshold, and excretion of bicarbonate again ceases.

The patients presented here demonstrate the same phenomenon, only at a lower threshold; bicarbonate appears in the urine at a time when the levels in serum 
are lower than that found in normal infants or adults. Serum bicarbonate concentration therefore remains significantly below normal and there is a resultant metabolic acidosis despite normal renal capacity to excrete hydrogen ion. Serum bicarbonate can be raised to the normal range by giving bicarbonate, but as soon as therapy is stopped acidosis quickly reappears, due not only to loss of bicarbonate into the urine as the threshold is exceeded, but also to inhibition of the distal mechanisms of hydrogen excretion by flooding the distal tubule with bicarbonate rich fluid. Only by giving large amounts of bicarbonate or citrate, with concomitant loss of large amounts of bicarbonate in urine, can levels of bicarbonate in serum be maintained within the normal range.

Mechanisms involved. The renal bicarbonate threshold was low in both patients but marked differences were found in the curves of bicarbonate reabsorption, suggesting two types of abnormality. The precise nature of the defective mechanisms cannot be elucidated from the present investigations but some explanations may be offered.

It is generally accepted that renal bicarbonate reabsorption occurs as a consequence of the secretion of cellular hydrogen ion into the tubular lumen [50]. Two independent mechanisms involved in bicarbonate reabsorption have been identified: 1. a carbonic anhydrase dependent mechanism, the enzyme presumably having both cellular and luminal action [53]; and 2. a $\mathrm{pCO}_{2}$ dependent mechanism which does not require cellular activity of carbonic anhydrase and is mediated by the uncatalyzed hydration of $\mathrm{CO}_{2}$ [54]. MAREN and Wiley have provided evidence that, in addition, a portion of filtered bicarbonate is reabsorbed as such without mediation of hydrogen secretion [41, 42].

On first examination a defect in carbonic anhydrase activity at the level of the tubular cell or the tubular lumen would seem to explain some of the data in our patients. Further analysis, however, reveals that this is not so. Experimental inhibition of carbonic anhydrase by acetazolamide depresses bicarbonate reabsorption, with a decrease in threshold, depression of $\mathrm{Tm}$, and increase of the titration splay [54]. Although carbonic anhydrase was not assayed in our cases, and a quantitative defect in carbonic anhydrase activity or concentration cannot be excluded, the following observations are against this possibility: 1. K.J. showed both a low threshold and a low $\mathrm{Tm}$, but had a normal splay; 2. S.G. had a low threshold and an abnormal splay, but a normal Tm; 3. bicarbonate reabsorption was inhibited significantly in both patients by administration of acetazolamide; and 4. gastric fluid with adequate acidity was obtained after histamine administration, providing evidence against a general disturbance in carbonic anhydrase activity.

The patterns of abnormality in bicarbonate reabsorption in these patients is strikingly similar to those found in the two types of renal glycosuria ${ }^{4}$.

Although glucose titration in K.J. was normal, as were all other tubular functions studied, demonstrating that the defect in bicarbonate reabsorption was an isolated one, it may be significant that the characteristics of his bicarbonate reabsorption titration are identical to those of type A renal glycosuria; he had a low threshold, low Tm, and normal splay. In type A renal glycosuria, the data have been interpreted as indicating a defect in the enzymatic mechanism controlling glucose reabsorption; similarly, a defect in the enzymatic mechanism controlling bicarbonate reabsorption could underly the abnormality in K.J. Although one can only speculate on the nature of this defect, it is of interest that his curve of bicarbonate reabsorption is similar to that obtained by infusing bicarbonate into dogs during controlled hypocapnia [63], a situation in which the limiting factor may be availability of hydrogen ion for bicarbonate reabsorption. This parallel suggests that a defect in diffusion or rate of secretion of hydrogen ion may underly the abnormality in this subject. Similarly, if a large moiety of bicarbonate reabsorption is performed without mediation of hydrogen secretion, as MAREN and WILEY have suggested [42], a defect in this mechanism could explain the abnormality in bicarbonate reabsorption.

In S. G. the low threshold, normal Tm and increased splay resemble type $B$ renal glycosuria; in fact, he actually had this type of abnormality in glucose reabsorption. Type $B$ renal glycosuria has been attributed to an exaggerated heterogeneity of nephrons in their capacity to reabsorb glucose [55]. A similar explanation may apply to the combined abnormality demonstrated in S.G. The defect in the proximal tubule could be functional (i.e. related to glomerulotubular imbalance) or anatomic; but the fact that it involved two different filtered substances may favor an increased disparity of the nephron population rather than specific defects in both the glucose and bicarbonate reabsorptive mechanisms. An alternative explanation, which cannot be excluded, is an abnormality in an unidentified common transport pathway. Metabolic acidosis or bicarbonate loss has not been reported in type B renal gly-

${ }^{4}$ Not all authors agree that there are, in fact, two types of renal glycosuria, but feel that so-called types A and $B$ represent different degrees of severity of the same defect $[45,47]$. Similarly, with the present data we cannot be certain that the differences demonstrated in the two patients reported here necessarily represent two different types of abnormality. 
cosuria. However, the defect could be mild and overlooked without specific studies and appropriate investigation of such patients should be undertaken.

\section{Bicarbonate Reabsorption in Secondary RTA}

Inappropriate bicarbonate loss has been reported in several conditions, in association with other abnormalities of glomerular or tubular function. The usual cause of metabolic acidosis in patients with chronic renal disease is nephron destruction and reduction in rate of glomerular filtration, with subsequent limitation in excretion of ammonium $[19,62,77]$ and availability of phosphate for production of tritratable acid $[23,24,28]$. The capacity to excrete a urine with low $\mathrm{pH}$ usually is intact $[19,23,24,28,62,77]$ and the Tm of reabsorption of bicarbonate has been found to be normal relative to the rate of glomerular filtration [58]. A low bicarbonate threshold, however, has been reported in some patients [32, 62]. This abnormality is similar to that found in S.G. although his glomerular function and renal histology were normal. It is possible that the bicarbonate reabsorption defect in patients with chronic renal insufficiency is also dependent on an increased hetcrogeneity of the remaining nephron population, although data on glucose titration in experimental chronic renal disease [66] may favor the hypothesis of altered enzyme kinetics due to hyperperfusion of residual nephrons.

The pathogenesis of the acidosis in patients with multiple tubular dysfunction is unclear. It is generally stated that there is an inability to excrete urine of low $\mathrm{pH}[45]$, but some of the patients reported were able to acidify urine quite well under conditions of metabolic acidosis. It is likely, therefore, that their abnormality was in bicarbonate reabsorption. This possibility has been suspected in the syndromes of FANCONI [46] and Lowe [13, 34, 57], although only a few bicarbonate reabsorption studies have been reported. In Fanconi syndrome low bicarbonate threshold $[7,48$, 59] and $\Gamma \mathrm{m}$ of reabsorption [48, 59] have been found, and when serum bicarbonate was below the threshold value patients have had acid urines and hydrogen excretion adequatc for the level of glomerular filtration [59]. In K. J., although all tests of tubular function other than bicarbonate reabsorption were normal, the possibility of a gradual sequential development of other tubular defects, as has been reported by LUDEN and Sheldon [40, 67] and Bloomer et al. [4], cannot be excluded. Abnormalities in bicarbonate reabsorption in patients with hereditary intolerance to fructose and medullary cystic disease also have been reported [48].

\section{Classification of $R T A$}

Prerious classifications. Available definitions and classifications of primary RTA are based solely on patients

7 P'ediat. Res.. Vol. 1, No. 2 (1967) whose defect is in the ability to establish normal hydrogen ion gradients. MILNE, for example definies RTA as the inability to acidify the urine below $\mathrm{pH} 5.4$ under the stimulus of ammonium chloride ingestion or spontaneous metabolic acidosis [45]. Elkinton et al. define RTA as an impairment of the ability of the kidney to excrete acid out of proportion to the impairment of glomerular filtration [20,31]. On the basis of these definitions, none of the patients with abnormal bicarbonate reabsorption could be classified under the heading RTA, despite their striking tubular abnormalities.

Primary RTA is usually classified into adult and infantile forms $[31,45]$. The adiult form, first recognized by Butler, Wilson and FARBer in 1936, and identified as a renal tubular disease by Albright et al. in 1946 , is characteristically a permanent abnormality. The infantile form was first recognized by Ligutwoon $[36,49]$ : patients were said to recover spontaneously at about 2 years of age [39]. At least 90 cases were reported in England between 1947 and 1953 [3, 8, 14, 39, 73] and a temporary immaturity of the renal tubule was suspected as a possible etiology [39]. When some of these subjects were investigated at an older age, they were reported to have normal responses to ammonium chloride administration [5].

The pathophysiology of the acidosis in these infants is unclear since few precise studies of hydrogen excretion were performed. In most of the cases the RTA was probably a manifestation of vitamin $\mathrm{D}$ intoxication, and thus should be classified as srcondary RTA. The peak incidence of the disease ccincided with that of idiopathic hypercalcemia. When the vitamin D content of milk was decreased, both diseases became rare. Toxicity duc to sulphonamides and mercury was also suspected. Isolated cases are still reported in England, although the details of their pathophysiology have not been given [37].

Most if not all children with primary RTA beginning in early infancy do not recover, despite adequate therapy. The existence of a transient form of primary $\mathrm{RTA}$ in infants is uncertain, therefore, if patients with acute dehydration or acute pyelonephritis are excluded. The inadequacy of classification according to age of onset is obvious $[37,65]$.

Proposed classification. We define RTA as a condition in which there is a defect in renal excretion of hydrogen ion or reabsorption of bicarbonate, or both, which is out of proportion to impairment of glomerular filtration. It is suggested that RTA be divided into two forms:

1. a proximal form caused by a defect in bicarbonate reabsorption; and 2. a distal form due to inability to establish an adequate $\mathrm{pH}$ gradient between blood 
and distal tubular fluid ${ }^{5}$. Although $\mathrm{pH}$ gradients are established throughout the length of the nephron and bicarbonate reabsorption is not confined to the proximal segment, most filtered bicarbonate is reabsorbed in the proximal tubule whereas production of ammonium and titratable acid with low urinary $\mathrm{pH}$ is primarily a distal function. Therefore, although the classification may not be entirely correct physiologically, it does have functional validity.

Proximal or distal RTA may be primary, i.e. isolated and idiopathic, or secondary, i.e. due to toxins, associated with various metabolic disorders, or a consequence of generalized renal disease.

Diagnosis of $R T A$. One important consequence of this classification is that demonstrating a urinary $\mathrm{pH}$ below 5.4 and adequate hydrogen excretion during spontaneous or induced metabolic acidosis does not rule out a renal tubular defect since under these circumstances an abnormality in the bicarbonate threshold could still be present. Conversely, the presence of an elevated urinary $\mathrm{pH}$ during metabolic acidosis may or may not represent a gradient defect which, if present, should be demonstrable at all levels of serum bicarbonate.

\section{Clinical and Physiological Comparisons between Proximal and Distal RTA}

Distinguishing between proximal and distal tubular acidosis has important clinical as well as physiological implications as shown in table VII. In our patients the only major clinical manifestation was failure to thrive, without the usual complications of RTA. Although the absence of complications in the present patients may be due in part to the early age of diagnosis, particularly in K.J., differences in complications may be due to differences in the natural history of the proximal and distal forms of RTA. During metabolic acidosis patients with proximal RTA excrete urine that is highly acid, with adequate amounts of titratable acid and ammonium. As a consequence, sodium and potassium are not lost in excessive amounts in the urine. Although hydrogen ion balances were not obtained in either patient, it seems likely that at low serum bicarbonate levels, a normal or near-normal balance was present between dietary intake and renal excretion, as compared with the situation in patients with distal renal

${ }^{5}$ Primary deficiencies in renal ammonia production or formation of titratable acid would constitute additional forms of distal RTA. However, an isolated defect in the renal ammonia mechanism has not been demonstrated, with the exception of the reports of renal abnormalities in gout [26, 27], and uric acid stone formers [30]. It is likely, however, that these situations do not represent primary defects in ammonium synthesis but rather
Table VII. Features of renal tubular acidosis

\begin{tabular}{|c|c|c|}
\hline & $\begin{array}{l}\text { Site of lesion } \\
\text { proximal }\end{array}$ & $\begin{array}{l}\text { Site of lesion } \\
\text { distal }\end{array}$ \\
\hline $\begin{array}{l}\text { Urinary } \\
\text { acidification } \\
\text { (pH) }\end{array}$ & $\begin{array}{l}\text { normal below } \\
\text { plasma bicarbo- } \\
\text { nate threshold }\end{array}$ & $\begin{array}{l}\text { impaired below } \\
\text { plasma bicarbo- } \\
\text { nate threshold }\end{array}$ \\
\hline $\begin{array}{l}\text { Hydrogen } \\
\text { excretion } \\
\left.\text { (T.A \& } \mathrm{NH}_{4}\right)\end{array}$ & $\begin{array}{l}\text { normal below } \\
\text { plasma bicarbo- } \\
\text { nate threshold }\end{array}$ & $\begin{array}{l}\text { impaired below } \\
\text { plasma bicarbo- } \\
\text { nate threshold }\end{array}$ \\
\hline $\begin{array}{l}\text { Bicarbonate } \\
\text { threshold }\end{array}$ & low & normal \\
\hline Bicarbonate $\mathrm{Tm}$ & low or normal & normal \\
\hline Therapy & $\begin{array}{l}\text { high dosage } \\
\text { alkali required } \\
(5-10 \mathrm{mEq} / \mathrm{kg} \text { / } \\
\text { day or more })\end{array}$ & $\begin{array}{l}\text { dosage easily } \\
\text { determined from } \\
\text { potential } \mathrm{H}^{+} \text {in } \\
\text { diet ( } 2-3 \mathrm{mEq} / \\
\mathrm{kg} / \text { day) }\end{array}$ \\
\hline \multirow[t]{3}{*}{ Complications } & $\begin{array}{l}\text { may be absent, } \\
\text { except for } \\
\text { growth retarda- } \\
\text { tion and slight } \\
\text { hypercalciuria }\end{array}$ & $\begin{array}{l}\text { growth retarda- } \\
\text { tion } \\
\text { nephrocalcinosis } \\
\text { cation wastage } \\
\text { concentrating } \\
\text { defect }\end{array}$ \\
\hline & & $\begin{array}{l}\text { hypercalciuria } \\
\text { osteomalacia or } \\
\text { rickets }\end{array}$ \\
\hline & & $\begin{array}{l}\text { interstitial } \\
\text { nephritis } \\
\text { uremia }\end{array}$ \\
\hline
\end{tabular}

tubular acidosis or chronic renal disease who are in a continuous positive balance of hydrogen ion, due to the limitation in renal excretion of acid [25]. Buffering of this excess hydrogen ion by bone salts has been offered as a possible explanation for the skeletal demineralization commonly found in RTA [25]. K.J. and S.G. had normal bony structure on $\mathrm{x}$-ray, no biochemical evidence of rickets, calciuria was only moderately elevated during acidosis, and nephrocalcinosis was not present histologically. Of course, metabolic acidosis per se may cause gradual leaching of bone and through inhibition of vitamin D activity may cause osteomalacia. This mechanism remains to be demonstrated, although

reflect the effects of aging and low rates of glomerular filtration [2, 44, 52]. Defective production of titratable acid results from inadequately acid urine or unavailability of buffer. The former has been discussed and exists in distal RTA. The latter has been described by ELKINTON [21], but appears to be an abnormality in phosphate metabolism and should not be considered true RTA. 
YoRK and YENDT [79] have reported a 44-year-old woman with osteomalacia associated with renal bicarbonate loss. The bone lesions in this patient were thought to have been due to chronic acidosis, although the role of vitamin $\mathrm{D}$ deficiency could not be excluded.

Interstitial nephritis in distal RTA is thought to develop as a consequence of nephrocalcinosis and potassium deficiency; it probably does not occur in proximal RTA.

\section{Treatment of $R T A$}

In contrast to patients with distal RTA in whom a dose of citrate or bicarbonate equivalent to dietary intake of potential $\mathrm{H}^{+}$is adequate to maintain acidbase balance $[19,45,65]$, patients with proximal RTA require inordinately high doses of citrate or bicarbonate to maintain serum bicarbonate levels within the normal range, due to the great loss of bicarbonate in urine. Failure of a patient with RTA to respond to usual doses of bicarbonate may be a clue that the defect is of the proximal type.

\section{Summary}

Abnormal bicarbonate reabsorption with normal urinary acidification has been demonstrated as the cause of primary renal tubular acidosis in two children, identifying a new form of this disease. Measurement of bicarbonate reabsorption in one child showed a low renal threshold, decreased maximal rate of reabsorption, and normal splay, suggesting either an abnormality in reabsorption of bicarbonate ion, or a diffusion defect or a limitation in rate of secretion of hydrogen ion into the proximal tubule. In the other child, the bicarbonate threshold was similarly depressed, maximal rate of reabsorption was close to normal, and the splay was markedly increased. This subject had similar abnormalities in glucose reabsorption, suggesting either a heterogeneity of nephrons affecting both reabsorptive mechanisms or, an abnormality in a common transport pathway.

The limitations of current classifications of renal tubular acidosis is discussed, particularly with regard to dividing patients into infantile and adult forms. It is proposed that renal tubular acidosis caused by abnormalities in bicarbonate reabsorption be termed proximal RTA, in contrast to the condition caused by acidification defects, termed distal RTA. Proximal and distal forms should be classified further as primary (idiopathic and isolated) or secondary. RTA may be transient or permanent although the former may exist only as a secondary abnormality.

There are major clinical differences between proximal and distal RTA, including particularly the need for greater dosage of bicarbonate or citrate in the proximal form, due to excretion of large amounts of bicarbonate in the urine. On physiological grounds it can be anticipated that most of the usual complications of RTA, such as cation wastage and nephrocalcinosis, may not occur in primary proximal RTA.

\section{Addendum}

During preparation of this report four additional children, investigated because of failure to thrive, have been shown to have primary proximal RTA. It is of interest that two are first cousins and that all the children are males.

\section{References and Notes}

1. Albright, F.; Burnett, C.H.; Parson, W.; ReiFenstein, E.C., Jr. and Roos, A.: Osteomalacia and late rickets. The various etiologies met in the United States with emphasis on that resulting from a specific form of renal acidosis, the therapeutic indications for each etislogical sub-group, and the relationship between osteomalacia and Milkman's syndrome. Medicine (Baltimore) 25: 399-479 (1946).

2. Barzel, U.S.; Sperling, O.; Frank, M. and De VRIES, A.: Renal ammonium excretion and urinary $\mathrm{pH}$ in idiopathic uric acid lithiasis. J. Urol. (Baltimore) 92: 1-5 (1964).

3. Boutourline-Young, H.J.: Nephrocalcinosis infantum with hyperchloraemic acidosis. Brit.med. J. $i$ : 181-183 (1949).

4. Bloomer, H.A.; Canary, J.J.; Kyle, L.H. and AuLD, R.M.: The Fanconi syndrome with renal hyperchloremic acidosis. Amer. J. Med. 33: $141-$ 149 (1962).

5. Buchanan, E.V. and Komrower, G. M.: The prognosis of idiopathic renal acidosis in infancy with observations on urine acidification and ammonia production in children. Arch. Dis. Childh. 33: 532 534 (1958).

6. Butler, A. M.; Wilson, J. L. and Farber, S. : Dehydration and acidosis with calcification at renal tubules. J. Pediat. 8: 489-499 (1936).

7. Calcagno, P. L. and D'Albora, J. B. : Renal acidbase disorders-Pathogenesis and management. Pediat. Clin. N.Amer. 11: 611 (Saunders, Philadelphia 1964).

8. Carré, I.J.; Wood, B.S.B. and Smallwood, W.C.: Idiopathic renal acidosis in infancy. Arch.Dis. Childh. 29: 326-333 (1954). 
9. Ghasson, A. L.; Grady, H.J. and Stanley, M.A.: Determination of creatinine by means of automatic chemical analysis. Amer.J.clin. Path. 35: 83-88 (1961).

10. Conway, E.J.: Microdiffusion analysis and volumetric error; 4th ed., p. 98 (Macmillan, New York 1952).

11. Cotrove, E.; Trantham, H.V. and Bowman, R. L.: An instrument and method for automatic, rapid, accurate, and sensitive titration of chloride in biologic samples. J. Lab. clin. Med. 51: 461-468 (1959).

12. CUTTER, R.D.: The normal gastric secretion of infants and small children following stimulation with histamine. J. Pediat. 12: 1-15 (1938).

13. Denys, P. and Corbeel, L. : Acidose rénale, hypokaliémie, nanisme et syndrome oculo-cérébral. Ann. paediat. (Basel) 203: 313-327 (1964).

14. DoxiAdis, S.A.: Idiopathic renal acidosis in infancy. Arch. Dis. Childh. 27: 409-427 (1952).

15. Edelmann, C. M., Jr.; Barnett, H. L.; Stark, H. ; Boichis, H. and Rodriguez Soriano, J.: A standardized test of renal concentrating capacity in children. In press.

16. Edelmann, C. M., Jr.; Boichis, H.; Rodriguez Soriano, J. and Stark, H.: Renal regulation of acid-base balance. II. Response of infants and children to acute ammonium chloride acidosis. In press.

17. Edelmann, C. M., Jr.; Rodriguez Soriano, J.; Boichis, H. and Stark, H.: An isolated defect in renal bicarbonate reabsorption as a cause of hyperchloremic acidosis. J. Pediat. 67: 946 (1965).

18. Edelmann, C. M., Jr.; Rodriguez Soriano, J.; Borchis, H.; Gruskin, A. B. and Acosta, M. : Renal regulation of acid-base balance. I. The reabsorption and excretion of bicarbonate in infants. In press.

19. Elkinton, J.R.: Renal acidosis: Diagnosis and treatment. Med. Clin. N.Amer. 47: 935 (Saunders, Philadelphia/London 1963).

20. Elkinton, J.R. and Huth, E.J.: Renal tubular acidosis. Ann. intern. Med. 54: 1290-1295 (1961).

21. Elkinton, J.R.; Huth, E.J.; Webster, G. D., Jr. and McCance, R.A.: The renal excretion of hydrogen ion in renal tubular acidosis. I. Quantitative assessment of the response to ammonium chloride as an acid load. Amer.J. Med. 29: 554-575 (1960).

22. Fiske, C. H. and Subbarrow, Y.: The colorimetric determination of phosphorus. J.biol. Chem. 66: 375-400 (1925).

23. Gonick, H.C.; Kleeman, C.R. and Maxwell, M.H.: Importance of buffer availability in the impaired acid excretion of chronic renal disease. Clin. Res. 10: 123 (1962).
24. Gonick, H.C.; Rubini, M.E. and Maxwell, M. H. : Mechanisms of renal acidosis. J. clin. Invest. 41: 1361 (1962).

25. Goodman, A.D.; Lemann, J., Jr.; Lennon, E.J. and Relman, A.S.: Production, excretion, and net balance of fixed acid in patients with renal acidosis. J. clin. Invest. 44: 495-506 (1965).

26. Gutman, A.B. and Yü, T.F.: On the nature of the inborn metabolic error(s) of primary gout. Trans. Ass.Amer. Phycns. 76: 141-151 (1963).

27. Gutman, A.B. and Yü, T.F.: An abnormality of glutamine metabolism in primary gout. Amer.J. Med. 35: 820-831 (1963).

28. Hall, P.W.: III. Factors limiting hydrogen ion excretion in renal disease. J.Lab.clin. Med. 58: 823-824 (1961).

29. Hastings, A. B. and Sendroy, J., Jr.: The effect of variation in ionic strength on the apparent first and second dissociation constants of carbonic acid. J. biol. Chem. 65: 445-455 (1925).

30. Henneman, P.H.; Wallach, S. and Dempsey, E.F.: The metabolic defect responsible for uric acid renal stone formation. J. clin. Invest. 41: 537542 (1962).

31. Huth, E.J.; Webster, G.D., Jr. and Elkinton, J.R.: The renal excretion of hydrogen ion in renal tubular acidosis, III. An attempt to detect latent cases in a family; comments on nosology, genetics and etiology of the primary disease. Amer. J. Med. 29: 586-598 (1960).

32. Keele, D.; Holliday, M. and Egan, T.: Renal bicarbonate excretion in children with renal acidosis. Amer. J. Dis. Child. 96: 629-630 (1958).

33. Kessler, G. and Wolfman, M.: An automated method for the simultaneous determination of calcium and phosphorus. Clin. Chem. 10: 686-703 (1964).

34. Lamy, M.; Frézal, J.; Rey, J. et Larsen, C.: Etude métabolique du syndrome de Lowe. Rev. franç. Etude. clin. biol. 7: 271-283 (1962).

35. LAtner, A.L. and Burnard, E.D.: Idiopathic hyperchloraemic renal acidosis of infants. (Nephrocalcinosis infantum.) Observations on the site and nature of the lesion. Quart.J.Med. 19: 285-301 (1950).

36. Lightwood, R.: Calcium infarction of kidney in infants. Arch. Dis. Childh. 10: 205 (1935).

37. Lightwood, R. and Butler, N.: Decline in primary infantile renal acidosis: aetiological implications. Brit. med.J. i: 855-857 (1963).

38. Lightwood, R.; Maclagan, N.F. and Williams, J.G. : Persistent acidosis in an infant : cause not yet ascertained. Proc. roy. Soc. Med. 29: 1431-1433 (1936). 
Proximal renal tubular acidosis. A defect in bicarbonate reabsorption with normal urinary .. 97

39. Licihtwood, R.; Payne, W.W. and Black, J.A.: Infantile renal acidosis. Pediatrics 12: 628-644 (1953).

40. Luder, J. and Sheldon, W.: A familial tubular absorption defect of glucose and aminoacids. Arch. Dis. Childh. 30: 160-164 (1955).

41. Maren, T.H.: Carbonic anhydrase kinetics and inhibition at $37^{\circ}$ : an approach to reaction rates in vivo. J. Pharmacol. exp.'Ther. 139: 129-139 (1963).

42. Maren, T.H. and Wiley, C. E.: The contribution of $\mathrm{CO}_{2}$ hydration to maximal renal acidification. Fed. Proc. 24: 582 (1965).

43. Marsh, W.H.; Fingerhut, B. and Kirsch, E.: Determination of urea nitrogen with the diacetyl method and an automatic dialyzing apparatus. Amer.J.clin. Path. 28: 681-688 (1957).

44. Metcalfe-Gibson, A.; McCallum, F. M.; MorRISON, R. B.I. and Wrong, O.: Observations on the genesis of uric acid calculi. Proc. 2nd int. Congr. Nephrol. Prague 1963; p.813 (Excerpta Medica, New York 1964).

45. Milne, M.D.: Renal tubular dysfunction; in STRauss and Welt's Diseases of the Kidney, pp. 786-840 (Little, Brown and Company, Boston 1963).

46. Milne, M.D.; Stanbury, S.W. and Thompson, A. E.: Observations on the Fanconi syndrome and renal hyperchloremic acidosis in the adult. Quart. J. Med. 21: 61-82 (1952).

47. Monasterio, G.; Oliver, J.; Muiesan, G.; ParDelli, G.; Marinozzi, V. and MacDowell, M.: Renal diabetes as a congenital tubular dysplasia. Amer.J. Med. 37: 44-61 (1964).

48. Morris, R. C. : Evidence for an acidification defect of the proximal renal tubule in cxperimental and clinical renal disease. J.clin.Invest. 45: 1048 (1966).

49. Nelson, N.: A photometric adaptation of the Somogyi method for the determination of glucose. J. biol. Chem. 153: 375-380 (1944).

50. Pitrs, R.F.: Physiology of the kidney and body fluids; p. 163 (Year Book Medical Publishers, Chicago 1963).

51. Pitts, R.F.; Ayer, J. L. and Schiess, W.A.: The renal regulation of acid-base balance in man. III. The reabsorption and excretion of bicarbonate. J.clin. Invest. 28: 35-44 (1949).

52. Pollak, V.E. and Mattenheimer, H.: Glutaminase activity in the kidney in gout. J.Lab.clin.Med. 66: 564-570 (1965).

53. Rector, F.C., Jr.; Carter, N.W. and Seldin, D.W.: The mechanism of bicarbonate reabsorption in the proximal and distal tubules of the kidney. J.clin. Invest. 44: 278-290 (1965).

54. Rector, F.C., Jr.; Seldin, D.W.; Roberts, A.D., Jr. and Sмrтн, J.S. : The role of plasma $\mathrm{CO}_{2}$ tension and carbonic anhydrase activity in the renal reabsorption of bicarbonate. J.clin. Invest. 39: 17061721 (1960).

55. Reubi, F. C.: Glucose titration in renal glycosuria: in Lewis and Wolstenholme's Ciba Foundation Symposium on the Kidney, p. 96 (Little, Brown and Company, Boston 1954).

56. Reynolds, T.B.: Observations on the pathogenesis of renal tubular acidosis. Amer. J.Med. 25: 503-515 (1958).

57. Richards, W.; Donnell, G.N.; Wilson, W.A.; Stowens, D. and Perry, T.: The oculo-cerebrorenal syndrome of Lowe. Amer. J. Dis. Child. 109: 185-203 (1965).

58. Roberts, K. E.; Randall, H.T.; Vanamee, P. and Popel., J.W.: Renal mechanisms involved in bicarbonate absorption. Metabolism 5: 404-418 (1956).

59. Rodriguez Soriano, J.; Boichis, H. and EdelMANN, C. M., Jr.: Bicarbonate reabsorption and hydrogen ion excretion in children with renal tubular acidosis. In press.

60. Royer, P.; Lestradet, H.; Nordmann, R.; MaThiev, H. and Rodriguez Soriano, J.: Etude sur quatre cas d'acidose tubulaire chronique idiopathique avec hypocitraturie. Sem. Hôp. Paris 38 : 808-818 (1962).

61. Schreiner, G.E.: Determination of inulin by means of resorcinol. Proc. Soc. exp. Biol. (N.Y.) 74: 117-120 (1950).

62. Schwartz, W.B.; Hall, P.W.; Hays, R.M. and RELMAN, A.S.: On the mechanism of acidosis in chronic renal disease. J.clin. Invest. 38: 39-52 (1959).

63. Schwartz, W. B.; Lemieux, G. and Falbriard, A.: Renal reabsorption of bicarbonate during acute respiratory alkalosis. J. clin. Invest. 38: $2197-$ 2201 (1959).

64. Seldin, D.W.; Rector, F. G.; Portwood, R. and Garter, N.: Pathogenesis of hyperchloremic acidosis in renal tubular acidosis. Proc. 1st Congr.int. Nephrol., p.725 (Karger, Basel/New York 1961).

65. Seldin, D.W. and Wilson, J.D.: Renal tubular acidosis; in Stanbury, Wyngaarden and FredRICKSON's The Metabolic basis of inherited disease; 2nd ed., p. 1230 (McGraw Hill, New York 1966).

66. Shankel, S.; Robson, A. M.; Rieselbach, R. and Bricker, N.S.: The effects of functional adaptations on nephron homogeneity in the diseased kidney of the rat. J.Lab.clin. Med. 66: 1020-1021 (1965).

67. Sheldon, W.; Luder, J. and WebB, B. : A familial tubular absorption defect of glucose and aminoacids. Arch. Dis. Childh. 36: 90-95 (1961). 
68. Smiтh, H.W.: Application of saturation methods to the study of glomerular and tubular functions in the human kidney; in Lectures on the Kidney, p. 85 (University of Kansas, Lawrence 1943).

69. Smith, H.W.; Finkelstein, N.; Aliminosa, L.; Crawford, B. and Graber, M.: The renal clearances of substituted hippuric acid derivatives and other aromatic acids in dog and man. J. clin. Invest. 24: 388-404 (1945).

70. Smith, H.W.; Goldring, W.; Chasis, H.; Ranges, H.A. and Bradley, S.E.: II. The application of saturation methods to the study of glomerular and tubular function in the human kidney. J. Mt Sinai Hosp. 10: 59-108 (1943).

71. Smith, L.H., Jr. and Schreiner, G. E. : Studies on renal hyperchloremic acidosis. J.Lab.clin. Med. 43: 347-358 (1954).

72. Somogyi, M.: Notes on sugar determinations. J. biol. Chem. 195: 19-23 (1952).

73. Stapleton, T.: Idiopathic renal acidosis in an infant with excessive loss of bicarbonate in the urine. Lancet $i$ : 683-685 (1949).

74. Taggart, J.V.: in Combined clinics on disorders of renal tubular function. Amer.J. Med. 20: 448461 (1956).

75. Tudvad, F. ; McNamara, H. and BarnetT, H. L. : Renal response of premature infants to administration of bicarbonate and potassium. Pediatrics 13: 4-16 (1954).
76. VAN Styke, D. D. and NeILl, J. M.: The determination of gases in blood and other solutions by vacuum extraction and manometric measurement. J. biol. Chem. 61: 523-573 (1924).

77. Wrong, O. and Davies, H.E. F.: The excretion of acid in renal disease. Quart.J. Med. 28: 259-313 (1959).

78. Yaffe, S.J.; Craig, J.M. and Fellers, F.X.: Studies on renal enzymes in a patient with renal tubular acidosis. Amer. J. Med. 29: 168-175 (1960).

79. York, S.E. and YENDT, E.F.: Osteomalacia associated with renal bicarbonate loss. Canad.med. Ass.J. 94: 1329-1342 (1966).

80. We acknowledge the important contribution of the following: Edna J.Francis, R.N., head renal nurse, Armida B. Martinez, Research Assistant, and the nursing and laboratory staff of the Renal Unit.

81. Presented in part at the Thirty-Fifth Annual Meeting of the Society for Pediatric Research, Philadelphia, Pa., May 4-6, 1965 [17].

82. This work was supported in part by Public Health Research Grants Nos. 5 TI HE 5267 and HE 05561 from the National Heart Institute; The Kidney Foundation of New York; The Health Research Council of New York, HRC U-1098; and the Sylvan League, Inc. 